\title{
POLA DAN INSIDENS PENYAKIT INFEKSI KULIT KARENA VIRUS DI DIVISI DERMATOLOGI ANAK POLIKLINIK KESEHATAN KULIT DAN KELAMIN RSUP PROF. DR. R. D. KANDOU MANADO TAHUN 2008 - 2012
}

\author{
Rita S. Tanamal \\ Mariani V. Lasut \\ Herry E. J. Pandaleke \\ Bagian Ilmu Kesehatan Kulit dan Kelamin \\ Fakultas Kedokteran Universitas Sam Ratulangi Manado \\ Email: rita.tanamal@yahoo.com
}

\begin{abstract}
Viral skin infections are commonly found among people of all ages, however, they are more often in infants and children. Viral diseases may manifest in mucocutaneus areas either as the result of viral replication in the epidermis or as a secondary effect of viral replication elsewhere in the body. This study aimed to describe the pattern and incidences of viral skin infections. This was a retrospectives study using medical records of new patients with viral skin infection between the age of 0-14 years in Pediatric Dermatology Division at Dermatoveneneorology Clinic of Prof. Dr. R. D. Kandou General Hospital Manado from 2008 to 2012, based on the incidence, age group, gender, and type of viral skin infections. The results showed that the viral skin infection was the third highest rank of skin diseases in children with the incidence of $14.88 \%$. Males $(61.03 \%)$ were more frequently affected than females (38.97\%), with a ratio of $1.56: 1$. The most affected age group was $5-14$ years old (77.33\%). The most frequent found was moluscum contagiosum $(52.59 \%)$ followed by verucca vulgaris (24.21\%), varicela (17.83\%), herpes zoster (3.28\%), and hand foot mouth disease (1.89\%). Conclusion: In this study, viral skin infections in males and in the age group of 5-14 years. Moluscum contagiosum was the most frequent found among all age groups, followed by verucca vulgaris, varicela, herpes zoster, and hand foot mouth disease.
\end{abstract}

Keywords: infection, viral, children

\begin{abstract}
Abstrak: Penyakit infeksi kulit karena virus dapat terjadi pada segala usia, tetapi lebih banyak pada anak-anak. Virus dapat menyebabkan timbulnya lesi kulit sebagai hasil dari replikasi virus di epidermis ataupun sebagai efek sekunder replikasi virus di tempat lain pada tubuh. Penelitian ini bertujuan untuk mengetahui pola dan insidens penyakit infeksi kulit karena virus. Penelitian dilakukan secara retrospektif dengan mengumpulkan catatan medis pasien baru infeksi kulit karena virus yang berusia 0-14 tahun di Poliklinik Kesehatan Kulit dan Kelamin RSUP Prof. Dr. R. D. Kandou Manado periode tahun 2008-2012, yang meliputi jumlah kasus baru, usia, jenis kelamin, dan jenis penyakit infeksi kulit karena virus. Hasil penelitian memperlihatkan penyakit infeksi kulit karena virus menempati urutan ke-3 penyakit kulit terbanyak pada anak dengan insidens $14,88 \%$, laki-laki (61,03\%) dan perempuan (38,97\%), dengan rasio 1,56:1. Kelompok usia terbanyak 5-14 tahun (77,33\%). Jenis penyakit infeksi kulit karena virus ialah: moluskum kontagiosum (52,59\%), veruka vulgaris (24,21\%), varisela $(17,83 \%)$, herpes zoster $(3,28 \%)$, dan hand foot mouth disease $(1,89 \%)$. Simpulan: Dalam penelitian ini, pasien anak dengan penyakit infeksi kulit akibat virus lebih banyak ditemukan pada laki-laki dan kelompok usia 5-14 tahun. Moluskum kontagiosum merupakan penyakit yang terbanyak ditemukan dan juga terbanyak pada semua kelompok usia, diikuti oleh veruka vulgaris, varisela, herpes zoster, dan hand foot mouth disease.
\end{abstract}

Kata kunci: infeksi, virus, anak 
Kulit merupakan organ tubuh yang berfungsi sebagai pelindung tubuh sehingga mudah terjadi iritasi atau infeksi. ${ }^{1}$ Struktur kulit anak dan dewasa serupa, tetapi kulit anak lebih peka dan fungsinya belum sempurna sehingga memudahkan terjadinya infeksi kulit. $^{2}$ Hampir semua anak pasti pernah mengalami infeksi kulit pada suatu waktu. ${ }^{3}$ Infeksi kulit dapat dicetuskan oleh beberapa hal, antara lain: kondisi imunologik, integritas kulit, status gizi, faktor lingkungan (panas dan kelembaban), serta kurangnya sanitasi dan higiene. ${ }^{4}$

Virus adalah organisme ultramikroskopik yang berkembang didalam sel hidup. ${ }^{1}$ Virus dapat menginfeksi kulit lewat autoinokulasi langsung, penyebaran lokal dari infeksi internal, atau lewat infeksi sistemik. $^{5} \quad$ Virus dapat menyebabkan timbulnya lesi kulit sebagai hasil dari replikasi virus di epidermis atau sebagai efek sekunder dari replikasi virus di tempat lain pada tubuh. ${ }^{5-6}$

Penyakit infeksi kulit karena virus dapat terjadi pada segala usia, tetapi lebih banyak terjadi pada anak-anak, ${ }^{7}$ terutama anak-anak usia sekolah. Hal ini dapat disebabkan aktivitas anak yang tinggi sehingga mempermudah untuk terpapar dengan agen penyebab infeksi. ${ }^{8}$

Di Indonesia, pola dan insidens penyakit infeksi kulit karena virus pada anak belum diketahui pasti. Pola dan insidens penyakit infeksi kulit karena virus pada anak di berbagai rumah sakit pendidikan di Indonesia bervariasi. Di Poliklinik Kulit dan Kelamin RSUP Dr. Mohammad Hoesin Palembang periode tahun 2005-2008, penyakit infeksi kulit karena virus pada anak ditemukan sebanyak 440 (13,56\%) dari 3246 pasien anak dan merupakan penyakit kulit ke-2 terbanyak pada anak, ${ }^{9}$ sedangkan di Poliklinik Kulit dan Kelamin RS Dr. M. Djamil Padang periode tahun 2003-2007, penyakit infeksi kulit tersebut merupakan penyakit kulit ke-5 terbanyak pada anak, yaitu sebanyak 187 (9,28\%) dari 2016 pasien anak. ${ }^{8}$ Di Manado, data yang dilaporkan periode tahun 2006-2008 terdapat 116 (20,31\%) pasien anak dengan penyakit infeksi kulit karena virus dari total 571 pasien anak dengan infeksi kulit di Divisi Dermatologi Anak Poliklinik Kesehatan Kulit dan Kelamin RSUP Prof. Dr. R.D. Kandou Manado. ${ }^{10}$

\section{METODE PENELITIAN}

Penelitian ini bersifat retrospektif deskriptif dengan cara mengumpulkan catatan medik pasien anak dengan penyakit infeksi kulit karena virus di Divisi Dermatologi Anak Poliklinik Kesehatan Kulit dan Kelamin RSUP Prof. Dr. R.D. Kandou Manado selama kurun waktu 5 tahun periode tahun 2008-2012. Pendataan dan penyusunan hasil penelitian dilakukan di Bagian Ilmu Kesehatan Kulit dan Kelamin Fakultas Kedokteran Universitas Sam Ratulangi Manado/RSUP Prof. Dr. R.D. Kandou Manado.

Populasi penelitian yaitu seluruh data pasien di buku register yang berobat di Divisi Dermatologi Anak Poliklinik Kesehatan Kulit dan Kelamin RSUP Prof. Dr. R.D. Kandou Manado periode tahun 2008-2012. Sampel penelitian yaitu semua data pasien baru dengan diagnosis penyakit infeksi kulit karena virus yang berobat di Divisi Dermatologi Anak Poliklinik Kesehatan Kulit dan Kelamin RSUP Prof. Dr. R.D. Kandou Manado periode tahun 2008-2012. Variabel penelitian ialah: jenis penyakit infeksi kulit karena virus, jenis kelamin, usia, dan jumlah kasus infeksi kulit karena virus. Definisi Operasional penelitian ini ialah:

1. Penyakit infeksi kulit karena virus yaitu: moluskum kontagiosum, veruka vulgaris, varisela, herpes zoster, hand foot mouth disease.

2. Jenis kelamin laki-laki dan perempuan

3. Usia pasien infeksi kulit karena virus saat datang berobat pada periode 20082012.

4. Klasifikasi kelompok usia anak berdasarkan WHO, yaitu: <1 tahun, 14 tahun, dan 5-14 tahun.

5. Jumlah kasus penyakit infeksi kulit karena virus yang ditemukan pada periode tahun 2008-2012. 


\section{HASIL PENELITIAN}

Penyakit infeksi kulit karena virus merupakan urutan ke-3 penyakit terbanyak pada Divisi Dermatologi Anak Poliklinik Kesehatan Kulit dan Kelamin RSUP Prof. Dr. R. D. Kandou Manado dari periode tahun 2008-2012 (Tabel 1). Selama kurun waktu 5 tahun terdapat 213 (14,88\%) pasien menderita penyakit infeksi kulit karena virus dari 1431 pasien anak di Divisi Dermatologi Anak Poliklinik Kesehatan Kulit dan Kelamin RSUP Prof. Dr. R. D. Kandou Manado (Tabel 2).

Tabel 1.Distribusi penyakit kulit pada anak di Poliklinik Kulit dan Kelamin RSUD Prof. dr. R.D. Kandou Manado Periode 2008 - 2012

\begin{tabular}{|c|c|c|c|c|c|c|}
\hline \multirow[b]{2}{*}{ Penyakit } & \multicolumn{5}{|c|}{ Tahun } & \multirow[b]{2}{*}{$\begin{array}{l}\text { Total } \\
(\%)\end{array}$} \\
\hline & $\begin{array}{l}2008 \\
(\%)\end{array}$ & $\begin{array}{c}2009 \\
(\%)\end{array}$ & $\begin{array}{c}2010 \\
(\%)\end{array}$ & $\begin{array}{c}2011 \\
(\%)\end{array}$ & $\begin{array}{c}2012 \\
(\%)\end{array}$ & \\
\hline Dermatitis & $\begin{array}{c}155 \\
(10,83 \%)\end{array}$ & $\begin{array}{c}106 \\
(7,41 \%)\end{array}$ & $\begin{array}{c}85 \\
(5,94 \%)\end{array}$ & $\begin{array}{c}82 \\
(5,73 \%)\end{array}$ & $\begin{array}{c}91 \\
(6,36 \%)\end{array}$ & $\begin{array}{c}519 \\
(36,27 \%)\end{array}$ \\
\hline $\begin{array}{l}\text { Penyakit infeksi karena } \\
\text { bakteri }\end{array}$ & $\begin{array}{c}60 \\
(4,19 \%)\end{array}$ & $\begin{array}{c}58 \\
(4,05 \%)\end{array}$ & $\begin{array}{c}76 \\
(5,31 \%)\end{array}$ & $\begin{array}{c}46 \\
(3,21 \%)\end{array}$ & $\begin{array}{c}56 \\
(3,91 \%)\end{array}$ & $\begin{array}{c}296 \\
(20,67 \%)\end{array}$ \\
\hline Penyakit infeksi & 52 & 42 & 56 & 30 & 33 & 213 \\
\hline karena virus & $(3,63 \%)$ & $(2,94 \%)$ & $(3,91 \%)$ & $(2,10 \%)$ & $(2,30 \%)$ & $(14,88 \%)$ \\
\hline $\begin{array}{l}\text { Penyakit infeksi karena } \\
\text { jamur }\end{array}$ & $\begin{array}{c}29 \\
(2,03 \%)\end{array}$ & $\begin{array}{c}10 \\
(0,69 \%)\end{array}$ & $\begin{array}{c}23 \\
(1,61 \%)\end{array}$ & $\begin{array}{c}14 \\
(0,98 \%)\end{array}$ & $\begin{array}{c}25 \\
(1,75 \%)\end{array}$ & $\begin{array}{c}101 \\
(7,06 \%)\end{array}$ \\
\hline Alergi & $\begin{array}{c}26 \\
(1,81 \%)\end{array}$ & $\begin{array}{c}15 \\
(1,05 \%)\end{array}$ & $\begin{array}{c}24 \\
(1,68 \%)\end{array}$ & $\begin{array}{c}11 \\
(0,77 \%)\end{array}$ & $\begin{array}{c}24 \\
(1,68 \%)\end{array}$ & $\begin{array}{c}100 \\
(6,99 \%)\end{array}$ \\
\hline $\begin{array}{l}\text { Penyakit } \\
\text { eritroskuamosa }\end{array}$ & $\begin{array}{c}16 \\
(1,12 \%)\end{array}$ & $\begin{array}{c}12 \\
(0,84 \%)\end{array}$ & $\begin{array}{c}4 \\
(0,28 \%)\end{array}$ & $\begin{array}{c}8 \\
(0,56)\end{array}$ & $\begin{array}{c}12 \\
(0,84 \%)\end{array}$ & $\begin{array}{c}52 \\
(3,64 \%)\end{array}$ \\
\hline Kelainan pigmen & $\begin{array}{c}8 \\
(0,56)\end{array}$ & $\begin{array}{c}15 \\
(1,05 \%)\end{array}$ & $\begin{array}{c}10 \\
(0,69 \%)\end{array}$ & $\begin{array}{c}4 \\
(0,28 \%)\end{array}$ & $\begin{array}{c}11 \\
(0,77 \%)\end{array}$ & $\begin{array}{c}48 \\
(3,35 \%)\end{array}$ \\
\hline $\begin{array}{l}\text { Penyakit infeksi karena } \\
\text { parasite }\end{array}$ & $\begin{array}{c}6 \\
(0,42 \%)\end{array}$ & $\begin{array}{c}9 \\
(0,63 \%)\end{array}$ & $\begin{array}{c}7 \\
(0,49 \%)\end{array}$ & $\begin{array}{c}5 \\
(0,35 \%)\end{array}$ & $\begin{array}{c}16 \\
(1,19 \%)\end{array}$ & $\begin{array}{c}43 \\
(3,01 \%)\end{array}$ \\
\hline $\begin{array}{l}\text { Kelainan kelenjar } \\
\text { sebasea dan kelenjar }\end{array}$ & $\begin{array}{c}4 \\
(0,28 \%)\end{array}$ & $\begin{array}{c}3 \\
(0,21 \%)\end{array}$ & $\begin{array}{c}9 \\
(0,63 \%)\end{array}$ & $\begin{array}{c}7 \\
(0,49 \%)\end{array}$ & $\begin{array}{c}7 \\
(0,49 \%)\end{array}$ & $\begin{array}{c}30 \\
(2,10 \%)\end{array}$ \\
\hline Tumor kulit & - & $\begin{array}{c}4 \\
(0,28 \%)\end{array}$ & $\begin{array}{c}3 \\
(0,21 \%)\end{array}$ & $\begin{array}{c}3 \\
(0,21 \%)\end{array}$ & $\begin{array}{c}3 \\
(0,21 \%)\end{array}$ & $\begin{array}{c}13 \\
(0,91 \%)\end{array}$ \\
\hline Kelainan vaskular & $\begin{array}{c}2 \\
(0,14 \%)\end{array}$ & $\begin{array}{c}1 \\
(0,07 \%)\end{array}$ & $\begin{array}{c}2 \\
(0,14 \%)\end{array}$ & $\begin{array}{c}4 \\
(0,28 \%)\end{array}$ & $\begin{array}{c}1 \\
(0,07 \%)\end{array}$ & $\begin{array}{c}10 \\
(0,70 \%)\end{array}$ \\
\hline Kelainan rambut & $\begin{array}{c}4 \\
(0,28 \%)\end{array}$ & $\begin{array}{c}1 \\
(0,07 \%)\end{array}$ & - & - & $\begin{array}{c}1 \\
(0,07 \%)\end{array}$ & $\begin{array}{c}6 \\
(0,42 \%)\end{array}$ \\
\hline Jumlah & $\begin{array}{c}362 \\
(25,29 \%)\end{array}$ & $\begin{array}{c}276 \\
(19,29 \%)\end{array}$ & $\begin{array}{c}299 \\
(20,89 \%)\end{array}$ & $\begin{array}{c}214 \\
(14,96 \%)\end{array}$ & $\begin{array}{c}280 \\
(19,61 \%)\end{array}$ & $\begin{array}{c}1431 \\
(100 \%)\end{array}$ \\
\hline
\end{tabular}

Tabel 2. Distribusi penyakit infeksi kulit karena virus pada anak di Poliklinik Kulit dan Kelamin RSUD Prof. dr. R.D. Kandou Manado Periode 2008 - 2012

\begin{tabular}{|c|c|c|c|c|c|c|}
\hline \multirow[b]{2}{*}{ Pasien } & \multicolumn{5}{|c|}{ Tahun } & \multirow[b]{2}{*}{$\begin{array}{c}\text { Jumlah } \\
(\%)\end{array}$} \\
\hline & $\begin{array}{l}2008 \\
(\%)\end{array}$ & $\begin{array}{l}2009 \\
(\%)\end{array}$ & $\begin{array}{c}2010 \\
(\%)\end{array}$ & $\begin{array}{c}2011 \\
(\%)\end{array}$ & $\begin{array}{c}2012 \\
(\%)\end{array}$ & \\
\hline $\begin{array}{l}\text { Penyakit infeksi } \\
\text { virus }\end{array}$ & $\begin{array}{c}52 \\
(3,63 \%)\end{array}$ & $\begin{array}{c}42 \\
(2,94 \%)\end{array}$ & $\begin{array}{c}56 \\
(3,91 \%)\end{array}$ & $\begin{array}{c}30 \\
(2,10 \%)\end{array}$ & $\begin{array}{c}33 \\
(2,30 \%)\end{array}$ & $\begin{array}{c}213 \\
(14,88 \%)\end{array}$ \\
\hline Penyakit lainnya & $\begin{array}{c}362 \\
(25,29 \%)\end{array}$ & $\begin{array}{c}276 \\
(19,29 \%)\end{array}$ & $\begin{array}{c}299 \\
(20,89 \%)\end{array}$ & $\begin{array}{c}214 \\
(14,96 \%)\end{array}$ & $\begin{array}{c}280 \\
(19,61 \%)\end{array}$ & $\begin{array}{l}1431 \\
(100)\end{array}$ \\
\hline
\end{tabular}


Tabel 3. Distribusi Penyakit infeksi kulit karena virus pada anak setiap tahun menurut usia

\begin{tabular}{ccccccc}
\hline $\begin{array}{c}\text { Usia } \\
\text { (tahun) }\end{array}$ & $\begin{array}{c}\mathbf{2 0 0 8} \\
\mathbf{( \% )}\end{array}$ & $\begin{array}{c}\mathbf{2 0 0 9} \\
\mathbf{( \% )}\end{array}$ & $\begin{array}{c}\mathbf{2 0 1 0} \\
\mathbf{( \% )}\end{array}$ & $\begin{array}{c}\mathbf{2 0 1 1} \\
\mathbf{( \% )}\end{array}$ & $\begin{array}{c}\mathbf{2 0 1 2} \\
\mathbf{( \% )}\end{array}$ & $\begin{array}{c}\text { Jumlah } \\
\mathbf{( \% )}\end{array}$ \\
\hline $0-<1$ & - & - & 1 & 1 & - & 2 \\
& & & $(0,47)$ & $(0,47)$ & & $(0,94)$ \\
$1-4$ & 8 & 6 & 13 & 6 & 12 & 45 \\
& $(3,76)$ & $(2,82)$ & $(6,10)$ & $(2,82)$ & $(5,63)$ & $(21,13)$ \\
$5-14$ & 44 & 36 & 42 & 23 & 21 & 166 \\
& $(20,65)$ & $(16,90)$ & $(19,72)$ & $(10,80)$ & $(9,86)$ & $(77,93)$ \\
\hline Jumlah & 52 & 42 & 56 & 30 & 33 & 213 \\
& $(24,41)$ & $(19,72)$ & $(26,29)$ & $(14,09)$ & $(15,49)$ & $(100)$ \\
\hline
\end{tabular}

Tabel 4. Distribusi penyakit infeksi kulit karena virus pada anak setiap tahun menurut jenis kelamin

\begin{tabular}{lcccccc}
\hline \multirow{2}{*}{$\begin{array}{l}\text { Jenis } \\
\text { Kelamin }\end{array}$} & $\mathbf{0 0 8}$ & $\mathbf{2 0 0 9}$ & $\mathbf{2 0 1 0}$ & $\mathbf{2 0 1 1}$ & $\mathbf{2 0 1 2}$ & $\begin{array}{c}\text { Jumlah } \\
\text { (\%) }\end{array}$ \\
\cline { 2 - 6 } & $\mathbf{2 0 )}$ & $\mathbf{( \% )}$ & $\mathbf{( \% )}$ & $\mathbf{( \% )}$ & $\mathbf{( \% )}$ & \\
\hline Laki-laki & 29 & 34 & 29 & 19 & 19 & 130 \\
& $(13,61)$ & $(15,96)$ & $(13,62)$ & $(8,92)$ & $(8,92)$ & $(61,03)$ \\
Perempuan & 23 & 8 & 27 & 11 & 14 & 83 \\
& $(10,80)$ & $(3,76)$ & $(12,67)$ & $(5,16)$ & $(6,57)$ & $(38,97)$ \\
\hline Total & 52 & 42 & 56 & 30 & 33 & 213 \\
& $(24,41)$ & $(19,72)$ & $(26,29)$ & $(14,09)$ & $(15,49)$ & $(100)$ \\
\hline
\end{tabular}

Distribusi menurut usia terbanyak pada kelompok usia 5-14 tahun sebanyak 166 (77,93\%) pasien, diikuti kelompok usia 1-4 tahun sebanyak 45 (21,13\%) pasien, dan kelompok usia $0-<1$ tahun sebanyak 2 (0,94\%) pasien (Tabel 3).

Selama kurun waktu 5 tahun (20082012) di Divisi Dermatologi Anak Poliklinik Kesehatan Kulit dan Kelamin RSUP Prof. Dr. R.D. Kandou Manado, ditemukan pasien laki-laki sebanyak 130 $(61,03 \%)$ dan perempuan sebanyak 83 (38,97\%) dengan ratio 1,56:1 (Tabel 4).

Data distribusi menurut jenis kelamin menunjukan bahwa moluskum kontagiosum, varisela, herpes zoster lebih banyak ditemukan pada pasien laki-laki, sedangkan veruka vulgaris dan hand foot mouth disease lebih banyak ditemukan pada pasien perempuan (Tabel 5).

Moluskum kontagiosum merupakan penyakit infeksi kulit karena virus terbanyak yang ditemukan selama kurun waktu penelitian dan juga terbanyak pada semua kelompok usia. Pada kelompok usia $0-<1$ tahun ditemukan 2 (0,94\%) pasien moluskum kontagiosum. Pada kelompok usia 1-4 tahun ditemukan moluskum kontagiosum sebagai jenis penyakit terbanyak yaitu 23 (10,80\%) pasien, diikuti varisela sebanyak 11 (5,16\%) pasien, veruka vulgaris sebanyak 7 (3,28\%) pasien, dan hand foot mouth disease sebanyak 4 (1,89\%) pasien. Pada kelompok usia 5-14 tahun ditemukan moluskum kontagiosum sebagai jenis penyakit kulit infeksi virus yang terbanyak yaitu 87 (40,85\%) pasien, diikuti veruka vulgaris sebanyak 45 (21,13\%), varisela sebanyak 27 (12,67\%) pasien, dan herpes zoster sebanyak 7 (3,28\%) pasien (Tabel 6). 
Tabel 5. Distribusi jenis penyakit infeksi kulit karena virus pada anak menurut jenis kelamin di Poliklinik Kulit dan Kelamin RSUD Prof. dr. R. D. Kandou Manado (Januari 2008-Desember 2012)

\begin{tabular}{lccc}
\hline \multirow{1}{*}{ Jenis Penyakit } & \multicolumn{2}{c}{ Jenis Kelamin } & Jumlah \\
\cline { 2 - 3 } & $\begin{array}{c}\text { Laki-laki } \\
(\%)\end{array}$ & $\begin{array}{c}\text { Perempuan } \\
(\%)\end{array}$ & \\
\hline Moluskum kontagiosum & 79 & 33 & 112 \\
& $(37,10)$ & $(15,49)$ & $(52,59)$ \\
Veruka vulgaris & 23 & 29 & 52 \\
& $(10,80)$ & $(13,61)$ & $(24,41)$ \\
Varisela & 22 & 16 & 38 \\
& $(10,32)$ & $(7,51)$ & $(17,83)$ \\
Herpes zoster & 5 & 2 & 7 \\
\multirow{2}{*}{ Hand foot mouth disease } & $(2,34)$ & $(0,94)$ & $(3,28)$ \\
& 1 & 3 & 4 \\
& $(0,47)$ & $(1,41)$ & $(1,89)$ \\
\hline \multirow{2}{*}{ Jumlah } & 130 & 83 & 213 \\
& $(61,03)$ & $(38,97)$ & $(100)$ \\
\hline
\end{tabular}

Tabel 6. Distribusi Jenis penyakit infeksi kulit karena virus pada anak menurut usia di Poliklinik Kulit dan Kelamin RSUD Prof. dr. R.D. Kandou Manado (Januari 2008-Desember 2012)

\begin{tabular}{ccccc}
\hline \multirow{2}{*}{ Jenis penyakit } & \multicolumn{3}{c}{ Kelompok usia } & $\begin{array}{c}\text { Jumlah } \\
\text { (\%) }\end{array}$ \\
\cline { 2 - 4 } & $0<1$ tahun & $1-4$ tahun & $5-14$ tahun & \\
\hline Moluskum & $(\%)$ & $(\%)$ & $(\%)$ & \\
kontagiosum & 2 & 23 & 87 & 112 \\
Veruka vulgaris & $(0,94)$ & $(10,80)$ & $(40,85)$ & $(52,59)$ \\
& - & 7 & 45 & 52 \\
Varisela & - & $(3,28)$ & $(21.13)$ & $(24,41)$ \\
& & 11 & 27 & 38 \\
Herpes zoster & - & $(5,16)$ & $(12,67)$ & $(17,83)$ \\
Hand foot mouth & - & - & 7 & 7 \\
disease & & 4 & $(3,28)$ & $(3,28)$ \\
Jumlah & 2 & $(1,89)$ & - & 4 \\
& $(0,94 \%)$ & $(21,13 \%)$ & $(77,93)$ & $(1,89)$ \\
\hline
\end{tabular}

\section{BAHASAN}

Di Indonesia, pola dan insidens penyakit kulit infeksi virus belum diketahui secara pasti. Pola dan insidens penyakit kulit infeksi virus di berbagai rumah sakit pendidikan di Indonesia bervariasi. Pada penelitian retrospektif ini didapatkan penyakit infeksi kulit karena virus menempati urutan ke-3 (12,29\%) penyakit terbanyak pada Divisi Dermatologi Anak Poliklinik Kesehatan Kulit dan Kelamin RSUP Prof. Dr. R. D. Kandou Manado periode tahun 2008-2012. Hal ini berbeda dengan penelitian Sylvia et al di RS Dr. M. Djamil, Padang (2008) ${ }^{8}$ yang menemukan penyakit infeksi kulit karena virus merupakan urutan ke-5 terbanyak penyakit kulit pada anak serta penelitian Hutahean dan Soenarto di RSUP Dr. Mohammad Hosein Palembang (2010) ${ }^{9}$ yang menemukan penyakit infeksi kulit karena virus merupakan penyakit ke-2 terbanyak penyakit kulit pada anak.

Diantara seluruh pasien kulit infeksi virus pada anak, paling banyak ditemukan 
pada kelompok usia 5-14 tahun sebanyak 202 (78,91\%), diikuti kelompok usia 1-4 tahun sebanyak 52 (20,31\%), dan kelompok usia $0-<1$ tahun sebanyak 2 (0,78\%) pada periode 2008-2012. Hal ini sesuai dengan penelitian Waworuntu et al (RSUP Prof. Dr. R. D. Kandou Manado, 2002), ${ }^{24}$ Suhariyanto (RSUD Dr. Soebandi Jember, 2006), ${ }^{2}$ Sylvia et al (RS Dr. M. Djamil Padang, 2008), ${ }^{8}$ Gaspersz et al (RSUP Prof. Dr. R.D. Kandou Manado, 2009) ${ }^{10}$ Hutahean dan Soenarto (RSUP Dr. Mohammad Hosein Palembang, 2010), ${ }^{9}$ yang juga menemukan bahwa penyakit kulit infeksi virus pada anak paling banyak terjadi di kelompok usia 5-14 tahun. Tingginya insidens penyakit infeksi kulit karena virus pada kelompok usia 5-14 tahun dikarenakan pada usia tersebut anak sudah mulai bersekolah ${ }^{1,13-14,19,21}$ dan aktivitas yang lebih banyak sehingga kemungkinan terjadinya kontak dengan lingkungan semakin tinggi, sehingga mempermudah transmisi atau penularan infeksi. ${ }^{8}$

Selama kurun waktu 5 tahun (20082012) di Divisi Dermatologi Anak Poliklinik Kesehatan Kulit dan Kelamin RSUP Prof. Dr. R.D. Kandou Manado, ditemukan pasien laki-laki sebanyak 130 (61,03\%) dan pasien perempuan sebanyak 83 (38,97\%) dengan ratio 1,56:1. Pada penelitian Waworuntu et al (RSUP Prof.Dr.R.D.Kandou Manado, 2002), ${ }^{24}$ Suhariyanto (RSUD Dr. Soebandi Jember, 2006), ${ }^{2}$ Gaspersz et al (RSUP Prof.Dr.R.D. Kandou Manado, 2009), ${ }^{10}$ Ratnasari dan Zulkarnain (RSU Dr. Soetomo Surabaya, 2009), ${ }^{25}$ juga ditemukan hal yang sama yaitu jumlah pasien laki-laki lebih banyak dari pasien perempuan.

Distribusi data menurut jenis kelamin menunjukkan bahwa moluskum kontagiosum, varisela, herpes zoster lebih banyak ditemukan pada pasien laki - laki dari pada pasien perempuan, kecuali untuk veruka vulgaris dan hand foot mouth disease yang lebih banyak ditemukan pada pasien perempuan daripada laki-laki. Herpes zoster paling banyak ditemukan pada pasien laki-laki; hal ini serupa dengan penelitian Gaspersz et al (RSUP Prof. Dr.
R.D. Kandou Manado, 2009), ${ }^{10}$ namun berbeda dengan acuan pustaka ${ }^{13}$ yang menyatakan herpes zoster lebih sering terjadi pada perempuan daripada laki-laki. Dari distribusi data didapatkan juga bahwa hand foot mouth disease paling banyak ditemukan pada pasien perempuan, yang juga berbeda dengan acuan pustaka ${ }^{20}$ yang menyebutkan bahwa insidens hand foot mouth disease lebih tinggi pada laki-laki dibandingkan perempuan.

Moluskum kontagiosum sebanyak 112 (52,59\%) pasien merupakan penyakit infeksi kulit karena virus terbanyak yang ditemukan selama kurun waktu penelitian dan juga terbanyak pada semua kelompok usia. Hal ini serupa dengan penelitian oleh Sylvia et al (RS Dr. M. Djamil Padang, 2008), ${ }^{8}$ serta Ratnasari dan Zulkarnain (RSU Dr. Soetomo Surabaya, 2009), ${ }^{25}$ yang juga menemukan bahwa moluskum kontagiosum merupakan jenis penyakit infeksi virus terbanyak pada anak. Urutan pertama ini agak berbeda dengan penelitan lainnya yang dilakukan oleh Waworuntu et al (RSUP Prof. Dr. R. D. Kandou Manado, 2002), ${ }^{24}$ Gaspersz et al (RSUP Prof. Dr. R. D. Kandou Manado, 2009), ${ }^{10}$ Suhariyanto (RSUD Dr. Soebandi Jember, 2006), ${ }^{2}$ yang menemukan bahwa varisela ialah jenis penyakit infeksi virus terbanyak pada anak sedangkan penelitian oleh Hutahean dan Soenarto (RSUP Dr. Mohammad Hosein Palembang, 2010) ${ }^{9}$ menemukan bahwa veruka vulgaris merupakan jenis penyakit infeksi virus terbanyak pada anak. Perbedaan urutan hasil penelitan ini mungkin dapat disebabkan karena pola dan insidens penyakit kulit karena infeksi virus pada anak di pengaruhi oleh banyak hal, antara lain: keadaan kulit anak, higiene, gizi, dan aktivitas sehari-hari. ${ }^{6}$

\section{SIMPULAN}

Dari sejumlah 1431 pasien anak di Divisi Dermatologi Anak Poliklinik Kesehatan Kulit dan Kelamin RSUP Prof. Dr. R.D. Kandou Manado periode tahun 2008-2012 terdapat 213 pasien anak dengan penyakit infeksi kulit akibat virus. 
Jumlah pasien laki-laki lebih banyak dari perempuan. Penyakit ini paling banyak ditemukan pada kelompok usia 5-14 tahun. Moluskum kontagiosum merupakan penyakit infeksi kulit karena virus terbanyak yang ditemukan dan juga terbanyak pada semua kelompok usia, diikuti oleh veruka vulgaris, varisela, herpes zoster, dan hand foot mouth disease.

Tingginya insidens penyakit tersebut mungkin dikarenakan pada usia ini anak sudah mulai bersekolah dan aktivitas menjadi lebih banyak sehingga kemungkinan terjadinya kontak dengan lingkungan semakin tinggi yang mempermudah transmisi atau penularan infeksi.

\section{DAFTAR PUSTAKA}

1. Paller AS, Mancini AJ. Hurwitz Clinical Pediatric Dermatology ( $3^{\text {rd }}$ ed). Philidelphia: Elsevier Saunders, 2006.

2. Suhariyanto B. Pola penyakit anak kulit anak di RSUD Dr. Soebandi Jember. MDVI. 2006;33(4):157-61.

3. Sladen MJ, Johnston GA. Common skin infections in children. [cited 2014 Mar 25]. BMJ. 2004;329:95-99 (home page on Internet). Available from: http: //dx.doi.org/10.1136/bmj.329.7457.95.

4. Boediardja SA. Epidemiologi penyakit infeksi serta peran sawar kulit pada infeksi mikroorganisme pada kulit bayi dan anak. In: Boediardja SA, Sugito TL, Kurniati DD, Elandari, editors. Infeksi Kulit pada Bayi dan Anak. Jakarta: Balai penerbit FK UI, 2003; p. 3-5.

5. Tyring SK. Cutaneus virology. In: Tyring SK, editor. Mucocutaneus Manifestations of Viral Diseases. New York: Marcel Dekker Inc, 2002; p.1-24.

6. Morrison KL, Ahmed A, Madkan V, Mendoza N, Tyring S. Viral Disease: General considerations. In: Goldsmith LA, Katz SI, Gilchrest BA, Paller AS, Leffel DJ, Wolff K, editors. Fitzpatrick's Dermatology in General Medicine $\left(8^{\text {th }}\right.$ ed). New York: McGraw Hill, 2012; p. 2329-36.

7. Caserta MT. Overview of viral infection in children. Merckmanuals.com (home page on internet). [cited 2014 Mar 25]. New Jersey: Merck \& Co.Inc., 2007.
Available from: www.merckmanuals. com/home/childrens_health_issues/vira l_infections_in_infants_and_children/o verview_of_viral_infections_in_childre n.html.

8. Sylvia L, Gustia R, Hakim Z, Isramihati, Lestari S, Yenny SW, et al. Pola penyakit kulit anak di Poliklinik Ilmu Kesehatan Kulit dan Kelamin RS Dr. M. Djamil Padang tahun 2003 -2007. Kumpulan naskah ilmiah Kongres Nasional ke-XII PERDOSKI 2-5 Juli 2008, Palembang.

9. Hutahean NB, Soenarto K. Pola dan insidens penyakit kulit pada anak di RSUP Dr. Mohammad Hoesin Palembang. MDVI. 2010;37(4):154-8.

10. Gaspersz S, Jackqueline S, Pandaleke HEJ, Kartini A. Penyakit kulit infeksi di Divisi Dermatologi Anak Poliklinik Kesehatan Kulit dan Kelamin RSUP Prof. Dr. R. D. Kandou Manado. Kumpulan makalah lengkap Pekan Ilmiah Tahunan ke-X PERDOSKI 2031 Oktober 2009, Jakarta.

11. Piggott W, Friedlander SF, Tom W. Poxvirus infection. In: Goldsmith LA, Katz SI, Gilchrest BA, Paller AS, Leffel DJ, Wolff K, editors. Fitzpatrick's Dermatology in General Medicine $\left(8^{\text {th }}\right.$ ed). New York: McGraw Hill, 2012; p. 2402-20.

12. Diven DG. Pox viruses. In: Tyring SK, editors. Mucocutaneus manifestations of viral diseases. New York: Marcel Dekker Inc., 2002; p. 39-68.

13. Wargon O. Human papiloma virus. In: Schchner LA, Hansen RC, editors. Pediatric Dermatology (4 $4^{\text {th }}$ ed). Philadelphia: Elsevier Mosby, 2011; p.1460-9.

14. Sterling JC. Virus infections. In: Burns DA, Breathnach SM, Cox NH, Griffths CEM, editors. Rook's Textbook of Dermatology ( $8^{\text {th }}$ ed). Massachussetts: Blackwell publishing Ltd, 2010; p. 1-78.

15. Androphy EJ, Kirnbauer R. Human papiloma virus infection. In: Goldsmith LA, Katz SI, Gilchrest BA, Paller AS, Leffel DJ, Wolff K, editors. Fitzpatrick’s Dermatology in General Medicine $\left(8^{\text {th }}\right.$ ed). New York: McGraw Hill, 2012; p. 2421-33.

16. Mansur CP. Human papilomaviruses. In: Tyring SK, editors. Mucocutaneus 
manifestations of viral diseases. New York: Marcel Dekker Inc., 2002; p. 247-94.

17. Schmader KE, Oxman MN. Varicella and herpes zoster. In: Goldsmith LA, Katz SI, Gilchrest BA, Paller AS, Leffel DJ, Wolff K, editors. Fitzpatrick's Dermatology in General Medicine $\left(8^{\text {th }}\right.$ ed). New York: McGraw Hill, 2012; p. 2383-401.

18. McCrary M, Brown TJ, Tyring SK. Varicella - zoster virus (Herpes 3). In: Tyring SK, editors. Mucocutaneus manifestations of viral diseases. New York: Marcel Dekker Inc., 2002; p. 119-44.

19. Wargon O. Varicella - zoster infections. In: Schachner LA, Hansen RC, editors. Pediatric Dermatology ( $4^{\text {th }}$ ed). Philadelphia: Elsevier Mosby, 2011; p. 1453-58.

20. James WD, Berger TG, Elston DM. Viral Disease. Andrews Diseases of the Skin Clinical Dermatology (11 ${ }^{\text {th }}$ ed). Philadelphia: Elsevier Saunders, 2011; p. 367-420.

21. Galen WK. Cutaneus manifestation of entrovirus infections. In: Tyring SK, editors. Mucocutaneus Manifestations of Viral Diseases. New York: Marcel
Dekker Inc, 2002; p. 455-472.

22. Mancini AJ. Viral exanthems. In: Schachner LA, Hansen RC, editors. Pediatric Dermatology (4 $4^{\text {th }}$ ed). Philadelphia: Elsevier Mosby, 2011; p.1425-43.

23. Belazarian L, Lorenzo ME, Pace NC, Sweeney SM, Wiss KM. Exanthematous viral disease. In: Goldsmith LA, Katz SI, Gilchrest BA, Paller AS, Leffel DJ, Wolff K, editors. Fitzpatrick's Dermatology in General Medicine $\left(8^{\text {th }}\right.$ ed). New York: McGraw Hill, 2012; p. 2337-66.

24. Waworuntu LV, Niode NJ, Pandaleke HEJ, Warouw WFTh. Infeksi virus pada anak di Bagian Ilmu Penyakit Kulit dan Kelamin RSUP Manado Januari 1998- Desember 2002. Tidak dipulikasikan.

25. Ratnasari DT, Zulkarnain I. Pola penyakit infeksi kulit pada bayi di Divisi Dermatologi Anak URJ Kesehatan Kulit dan Kelamin RSUD Dr. Soetomo Surabaya Periode 20052007. Kumpulan makalah lengkap Pekan Ilmiah Tahunan ke-X PERDOSKI 20-31 Oktober 2009, Jakarta. 